\title{
Employee Acceptance Decision Support System Using The Smart Method (Case Study on Association of The Indonesian Electrical and Mechanical Contractors Samarinda City)
}

\author{
Aldy Septian Derry \\ STMIK Widya Cipta Dharma, \\ Samarinda, 75123, Indonesia \\ aldisept022@gmail.com \\ * Corresponding author
}

\author{
Bartholomius Harpad id \\ STMIK Widya Cipta Dharma, \\ Samarinda, 75123, Indonesia \\ amelia@wicida.ac.id
}

\author{
Yunita id \\ STMIK Widya Cipta Dharma, \\ Samarinda, 75123, Indonesia \\ yunita@wicida.ac.id
}

Received: 2021-03-03; Revised: 2021-04-12; Accepted: 2021-04-30; Published: 2021-06-01

\begin{abstract}
Decision Support System (DSS) is a system that can assist someone in making accurate and targeted decisions. Many problems can be solved by using SPK, one of which is the acceptance of employees at the Gaklimdo Samarinda Association using the SMART (Simple Multi Attribute Rating Technique) method. The purpose of this research is to produce a Decision Support System for Employee Admission Using the SMART Method (Case Study of the Gaklimdo Association of Samarinda City) with the hope that the selection of employees will be carried out objectively. By using the PHP programming language and the database used is MySql. In this study, the data collection techniques used were literature study, observation and interviews. The result of this research is the creation of a decision support system to make employee decisions that are accepted, and not accepted as employees. Users can input prospective employee data, criteria data and sub-criteria data. Then the system will look for a solution using the SMART (Simple Multi Attribute Rating Technique) method. After the decision is obtained, the system will display the decision.
\end{abstract}

Keywords- Decision Support System, Employee Admission, SMART

\section{INTRODUCTION}

Labor or employees are one of the determining factors for the success of a company, qualified employees will make it easier for the company to manage its activities so that the goals set can be achieved. To obtain a qualified workforce is by selecting or selecting prospective workers. The main purpose of the selection process is to find the right person for a certain position, so that that person is able to work optimally and can stay in the company for a long time. (Arief, 2011; Chafffey, 2011).

The Association of Indonesian Electrical and Mechanical Contractors Association (GAKLIMDO) Samarinda is one of the associations established in 2014 which aims to issue certificates including Business Entity Certificate (SBU) Certificate of Expertise (SKA) and
Certificate of Skills (SKT) in fulfilling auction requirements. especially in the field of construction services. The selection process for recruiting employees at the Gaklimdo Association at this time still uses the conventional method, where all prospective employee data is only stored in the form of files or written documents, this results in the processing of prospective employee data taking a long time, mistakes often occur so that many prospective employees or applicants who do not meet the criteria or needs of the company can be accepted to work in the company.

Decision Support System (DSS) or Decision Support System (DSS) is a system that is able to provide problemsolving and communication capabilities for problems with semi-structured and unstructured conditions. This system is used to assist decision making in semistructured and unstructured situations, where no one knows exactly how decisions should be made.

The existence of this Decision Support System (DSS) is very beneficial for many people. One example in the Gaklimdo Association, in this case it is still inadequate in making specific decisions to solve problems, especially for hiring employees, therefore the Decision Support System (DSS) is one of the sufficient components in the Information System to be made as a way to fulfill needs.

The model used in the employee recruitment decision support system is the SMART method, the SMART method is chosen because the calculation is simpler so that there is no need for complex mathematical calculations with a strong mathematical understanding. (Novianti, 2016) Therefore, the researcher took the title "Support System Employee Admission Decisions Using the SMART Method (Case Study of the Association of Joint Contractors and Mechanics (GAKLIMDO) Samarinda City) ".

\section{LITERATURE REVIEW}

A. System

The system is defined as a set of interrelated and interconnected procedures to carry out a task together. 
Broadly speaking, an information system consists of three main components. The three components include software, hardware, and brainware that are interrelated with each other (Pratama, 2014; Jayan, 2010).

The system is a network of procedures created according to an integrated pattern to carry out the main activities of the company, while the procedure is a sequence of clerical activities, usually involving several people in one or more departments that are designed to ensure uniform handling of corporate transactions that occur repeatedly. (Ichwan, 2011; Prasetio, 2012).

There are two basic groups of approaches in defining the system, namely those based on the approach to the procedure and those based on the component approach.

1. System Approach and Procedure

A system is a network and procedures that are interrelated and work together to do a job or solve a particular problem.

2. System Approach and Its Components

A system is a collection of several elements that interact regularly to form a totality to solve a particular problem (Mulyadi, 2010).

\section{B. Decision Support System}

Decision support systems are systems that produce specific information aimed at a problem that must be solved by managers at various levels. (Quadir \& Farooq, 2010)

A decision support system is also a computer-based information system that produces various alternative decisions to assist management in dealing with various structured problems using data or models.

Decision support system (DSS) supported by a computerbased information system can help someone improve their performance in decision makers (Rosa \& Shalahuddin, 2014). A manager in a company can solve semi-structured problems, so managers and computers must work together as a problem-solving team in solving problems that are in a semi-structured area (Pratiwi, 2016; Ladjamudin, \& Al 2013).

When modeling in DSS development, the following steps are taken:

1. Feasibility Study (Intelligence)

In this step, goals are determined and procedure searches are carried out, data collection, problem identification, problem ownership identification, problem classification, and finally a problem statement is formed.

2. Design (Design)

At this stage, the model to be used and the criteria will be formulated. After that, look for an alternative model that can solve these problems. The next step is to predict the possible outcomes. Then the model variables are determined (Madcom, 2016).

3. Election (Choice)

After the design stage various alternative models and their variables were determined. At this stage, the model selection will be carried out, including the solution to the model. Furthermore, a sensitivity analysis was carried out, namely by replacing several variables. (Kadir, 2011; Madcoms, 2010).

4. Create a DSS

After determining the model, the following implements it in the DSS application.

Judging from the level of technology, DSS is divided into 3, namely:

1) Specific Decision Support System (DSS). Aims to help solve a problem with certain characteristics.

2) Decision Support System (SPK) Generators. A special software used to build and develop DSS. The SPK generator will make it easier for designers to build specific SPKs.

3) Decision Support System Equipment (DSS). In the form of software and hardware that is used or supports the construction of specific SPK and SPK generators (Pratama, 2014; Purbadian, 2016).

Based on the level of support, the DSS is divided into 6, namely:

1) Retrieve Information Elements. This is the lowest support that a DSS can provide, namely in the form of selective access to information.

2) Analyze Entire File. In this stage, managers are given access to view and analyze a complete file.

3) Prepare Reports from Multiple Files. This kind of support tends to be needed since managers deal with many activities with one particular moment.

4) Estimate Decision Consequences. In this stage, it is possible for managers to see the impact of every possible decision.

5) Propose Decision. Support at this stage is a bit more advanced. An alternative decision can be presented before the manager for consideration.

6) Make Decision. This is the kind of support one would expect from a DSS. This stage provides a decision that is just waiting for the legitimacy of the manager to run.

\section{RESEARCH METHODS}

\section{A. Login Flowchart}

The login flowchart starts by entering the username and password if the login is not successful, then reentering the username and password if successful then going to the main page, can be seen in Picture 1 . 


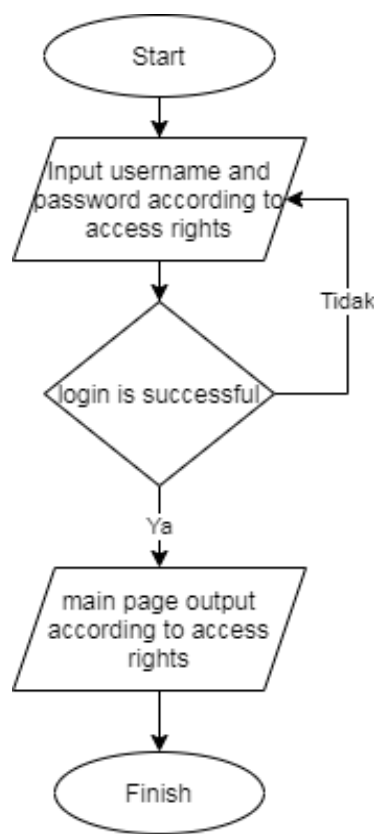

Picture 1. Login Flowchart

\section{B. Flowchart Calculation of the SMART Method}

The calculation flowchart of the SMART method, begins with the input of criteria and weights, then processed in the normalization of weights, then input the sub-criteria value, then calculates the utility value of each sub-criterion and calculates the final value, then outputs the results of the decision, and finished (Pranatha, 2019). Can be seen in Picture 2.

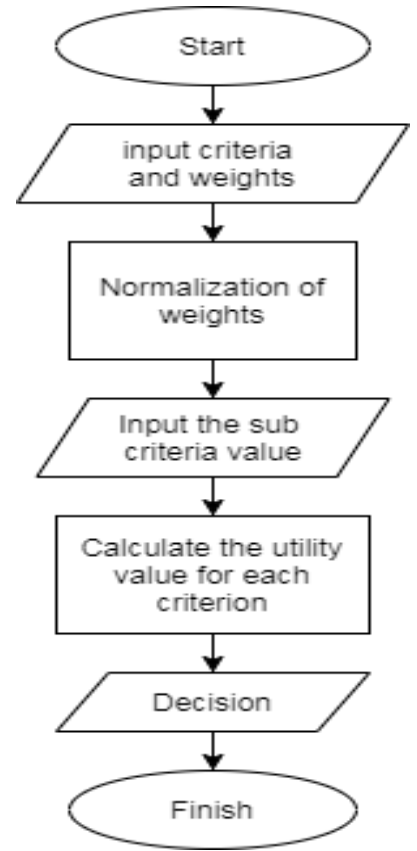

Picture 2. Flowchart of SMART Method Calculation

\section{Sitemap}

Sitemap of the decision support system for hiring employees at the Gaklimdo Association in Samarinda City. There are two access rights, namely admin containing Dashboard, Admin Data, Criteria Data, Alternative Data, Calculation Results, and Calculation
Reports, while the Leader contains Calculation Reports. Can be seen in Picture 3.

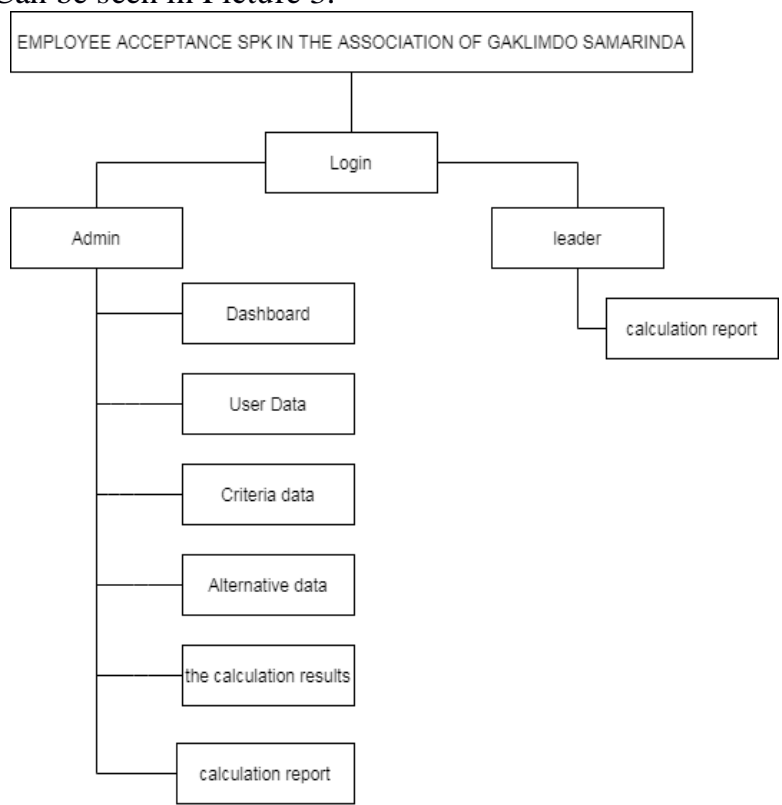

Picture 3. Sitemap

\section{Database Design}

The database design required for the Employee Admission Decision Support System Using the SMART Method (Case Study of the Gaklimdo Association in Samarinda City) is as follows:

1. Criteria Table

The criteria table can be seen in Table 1 .

Table 1. Criteria Table

\begin{tabular}{|c|c|c|c|}
\hline Field Name & Type & Size & Description \\
\hline id $*$ & Integer & 11 & Criterion id \\
\hline name & Varchar & 30 & Criteria name \\
\hline weight & Double & - & Criteria weights \\
\hline
\end{tabular}

2. Table Sub Criteria

The sub-criteria table can be seen in Table 2 .

Table 2. Sub Criteria Table

\begin{tabular}{|c|c|c|c|}
\hline Field Name & Type & Size & Description \\
\hline id $*$ & Integer & 11 & Sub criteria id \\
\hline criteria_id & Integer & 11 & Criterion id \\
\hline name & Varchar & 30 & Criteria name \\
\hline utility & Double & - & Utility value \\
\hline
\end{tabular}

3. Criteria Alternative Table

The alternative criteria table can be seen in Table 3 .

Table 3. Criteria Alternative Table

\begin{tabular}{|c|c|c|c|}
\hline Field Name & Type & Size & Description \\
\hline id $*$ & Integer & 11 & Alternative id criteria \\
\hline alternative_id & Integer & 11 & Alternative id \\
\hline criteria_id & Integer & 11 & Criterion id \\
\hline sub_kriteria_id & Integer & 11 & Sub Criteria Id \\
\hline
\end{tabular}




\section{User Table}

The user table can be seen in Table 4.

Table 4. User Table

\begin{tabular}{|c|c|c|c|}
\hline Field Name & Type & Size & Description \\
\hline id $*$ & Integer & 11 & User Id \\
\hline name & Varchar & 30 & User Name \\
\hline username & Varchar & 30 & Username User \\
\hline password & Varchar & 40 & User Password \\
\hline
\end{tabular}

\section{Alternative Tables}

An alternative table can be seen in Table 5 .

Table 5.Incoming Goods Details Table

\begin{tabular}{|c|c|c|c|}
\hline Field Name & Type & Size & Description \\
\hline id $*$ & Integer & 11 & Alternative id \\
\hline name & Varchar & 30 & Alternative name \\
\hline hp & Varchar & 15 & Alternative mobile number \\
\hline address & Varchar & 50 & Alternative Address \\
\hline
\end{tabular}

\section{RESULTS AND DISCUSSION}

\section{A. Login page}

The admin login page is a page for admins to enter the admin back-end page by entering the correct username and password then clicking the login button. Can be seen in Picture 4

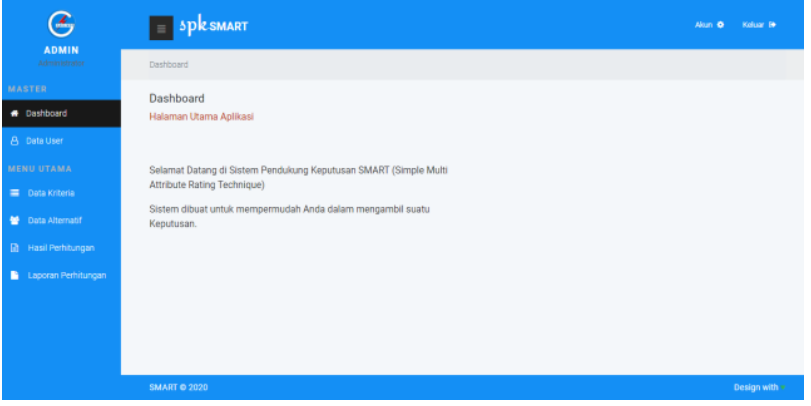

Picture 5. Dashboard page

\section{User Data page}

The User Data page is a page for admins to manage user data, as for the buttons available in the admin management page as follows:

1. The plus button is used to add user data.

2. The edit button functions to change the user data that you want to change.

3. The delete button functions to delete user data that you want to delete.

Can be seen in Picture 6.

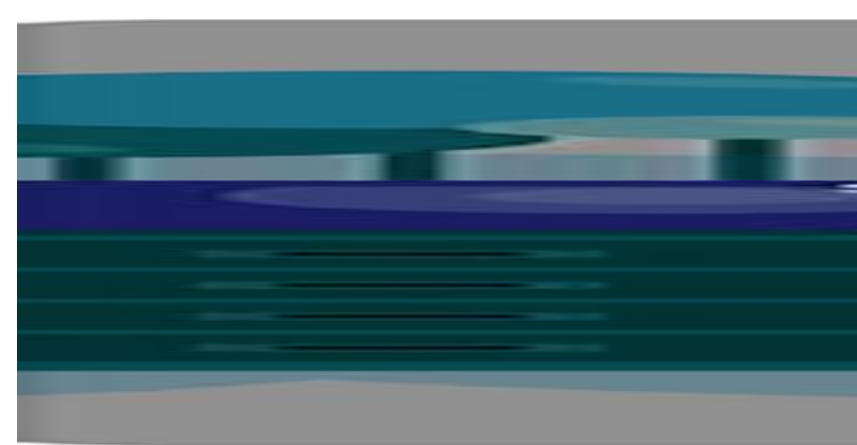

Picture 4. Login page

\section{B. Admin Dashboard page}

The admin dashboard page is the admin start page for managing the system (Wibowo, 2011). There are several menus including: User Data menu, Criteria Data, Alternative Data, Calculation Results and Calculation Reports. Can be seen in Picture 5 ..

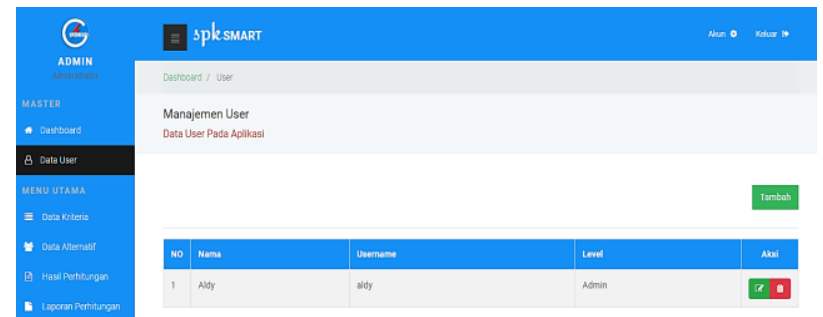

\section{Criteria Datapage}

The eriteria data page is a page for admins to

nanage criteria data. The buttons available on the criteria

The add criteria button is used to add .data

criteria and sub criteria.

2. The edit button functions to change the criteria data and .sub criteria that you want to change.

3. The delete button functions to delete the criteria data. And sub criteria that you want to delete.

Can be seen. In Picture 7.

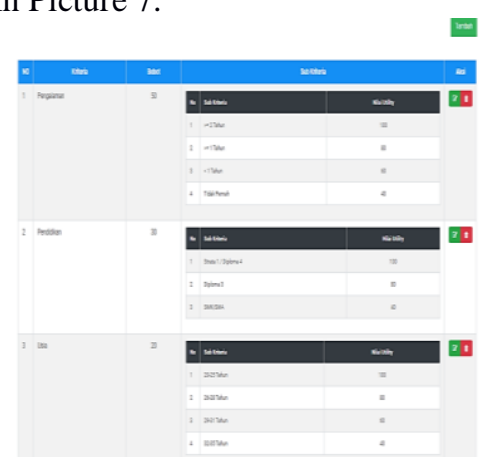

Picture 7. Criteria Data page 


\section{E. Alternative Data Pages}

Alternative data view is a page for admins to manage alternative data. Can be seen in Picture 8.

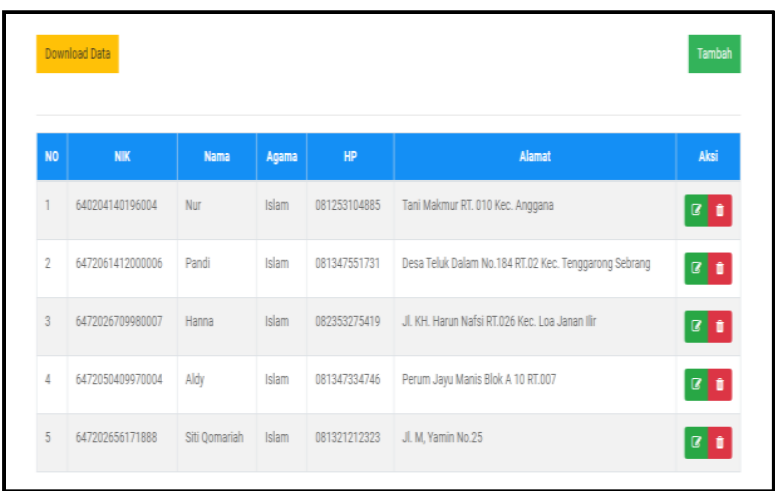

Picture 8. Alternative Data page

\section{F. Calculation Results page}

The calculation results page is a page for admins to view the value and results of calculations using the SMART method (Nawawi, 2011). The stages on the calculation results page are as follows:

1. Display Criteria and Sub Criteria

Display criteria and sub criteria can be seen in Picture 9.

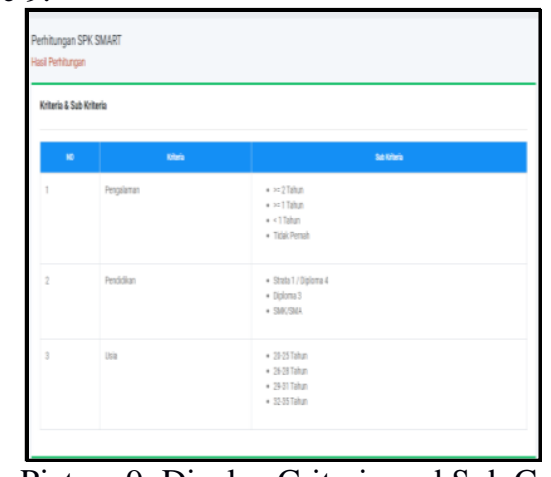

Picture 9. Display Criteria and Sub Criteria

2. Display Criteria Weights and Normalized Criteria Weights.

Display of criteria weight and normalization of criteria bobt can be seen in Picture 10 .

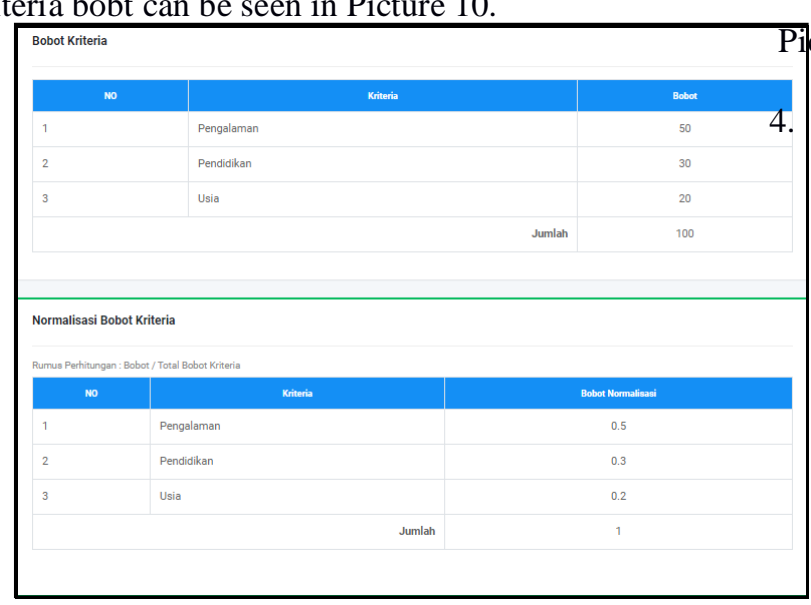

Picture 10. Display Criteria Weights and Weight Normalization. Criteria
3. Utility Value Display of Sub Criteria

The utility value display of the sub criteria can be seen in Picture 11.

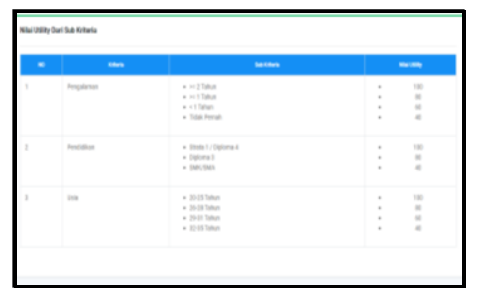

Picture 11. Display Utility Value of Sub Criteria

4. Display the Utility Value of Each Alternative The utility value display for each alternative can be seen in Picture 12.

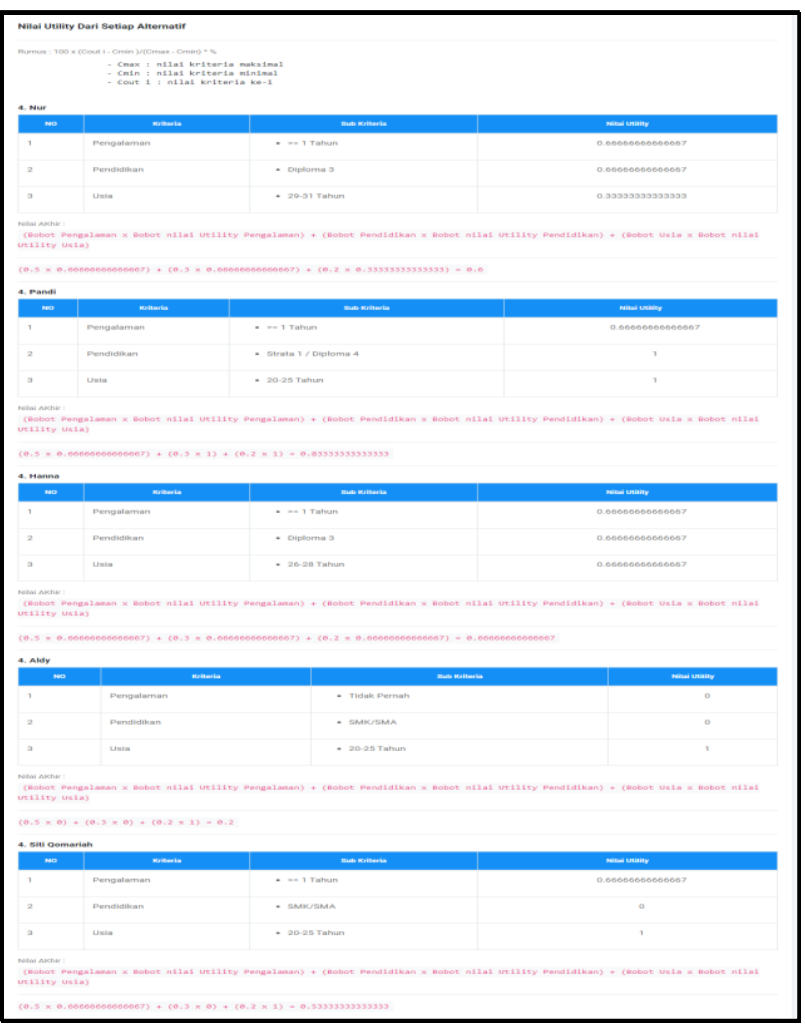

Picture 12. Display of Utility Value of Each Alternative.

Display of Decision Value and Results of Alternatives.

Display of the decision value and the results of the alternatives can be seen in Picture 13 


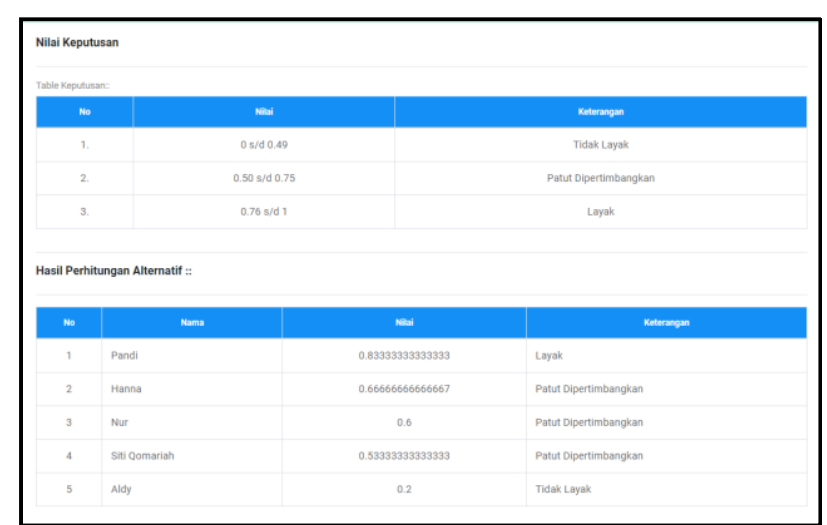

Picture 13. Display of Decision Values and Results of Alternatives

\section{G. Calculation Report Page}

The Calculation Report page is a display for admins to view and print value reports or calculation results using the SMART method. Can be seen in Picture 14

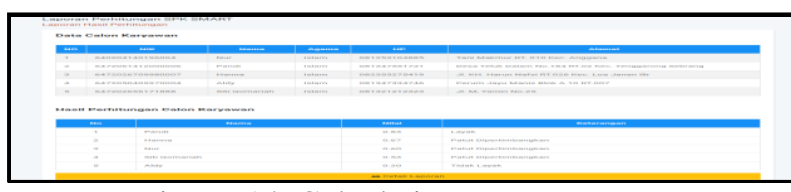

Picture 14. Calculation Report page

\section{H. Leadership Main Page}

Main Admin page is the initial display when the leader logs in. The menu for the leader is the calculation report, which is used to view and print the value report or calculation result using the SMART method. Can be seen in Picture 15.

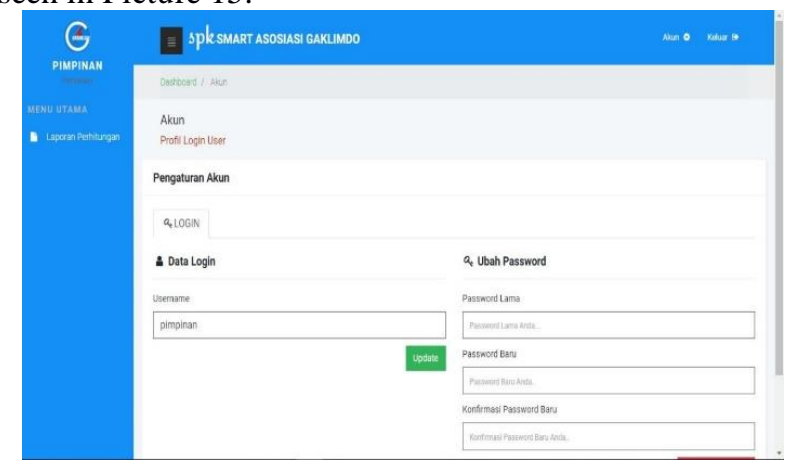

Picture 15. Main page of the leadership

\section{CONCLUSSION}

This employee recruitment decision support system is made using the programming languages PHP, CSS, HTML, Javascript, and MySQL as the database using flowchart and sitemap system development tools.

The design and manufacture of a Decision Support System for Employee Admission Using the Simple Multi Attribute Rating Technique method has been produced (Case Study of the Gaklimdo Association in Samarinda City.
The employee recruitment decision support system fulfills the needs of the Gaklimdo Samarinda Association to assist in hiring employees according to the required criteria. Based on the conclusions that have been stated above, the authors provide the following suggestions. In further development, it is hoped that a decision support system will be made not only for hiring employees but can be continued with the selection of outstanding employees. It is hoped that this application will serve as an additional reference for students in the field of information systems. This Decision Support System can be developed using methods other than the SMART method so that it can be compared to get more effective results.

\section{REFERENCES}

Arief, MR 2011. Dynamic Web Programming using PHP and MySQL. Cv Andi Offset. Yogyakarta.

Chaffey, D. (2011). E-Business and E-Commerce Management: Strategy, Implementation, and Practice. Pearson Education.

Ichwan, M., 2011. Database Programming Delphi 7 and MySQL, Bandung: Informatics.

Jayan, 2010. CSS for the Layman, first edition. Maxicom., Palembang.

Kadir, A. 2011, JQuery and PHP Smart Books, Yogyakarta: MediaKom.

Ladjamudin, \& Al-Bahra Bin, 2013. Analysis and Design of Information Systems. Yogyakarta: Graha Science.

Madcoms, A. 2010. Adobe Dreamweaver CS5 with PHPMySQL Programming. Publisher. CV Andi Offset.

Madcom, A. 2016. PHP and MySQL Programming For Beginners. Yogyakarta: CV Andi Offset.

Mulyadi, 2010. Accounting Systems, 3rd Edition, 5th edition. Publisher Salemba Empat, Jakarta.

Nawawi, 2011, Human Resource Management: Competitive Business Unzuk, Gajahmada University Press, Yogyakarta

Novianti, D. 2016. Web-Based Decision Support System for Café Selection Using the SMART (Simple Multi-Attribute Rating Technique) Method. Samarinda: Mulawarman University.

Pranatha, LA 2019. Decision Support System for Medical Personnel Admission Using the SMART Method (Case Study of Linggang Bigung Community Health Center). Samarinda: Widya Cipta Dharma College of Informatics and Computer Management.

Prasetio, A. 2012. Smart Book of WEB Programming. Jakarta: Our Media.

Pratama, 2014. Information Systems and Implementation, Bandung: Informatics Bandung.

Pratiwi, H. 2016. Textbook of Decision Support Systems, deepublish: Yogyakarta.

Purbadian, Y, 2016. Quick Tricks to Build Web-Based Applications with CodeIgniter Framework, Publisher Andi, Yogyakarta.

Quadri, SMK, and Farooq, SU 2010. Software TestingGoals, Principles, and Limitations. International Journal of Computer Application, 6 (9), 1. 
Rosa, AS, and Saladin, M, 2014. Structural and ObjectOriented Software Engineering. Bandung: Informatics.

Wibowo. 2011. Decision Support System Design, Depok, 2011. 